\title{
Purification, Characterization and Immobilization of Alginase Produced by Bacillus sp Associated with Sargassum wightii
}

\author{
Thiruvengadam Shankar, Thangavel Sivakumar*, Chandrahasan Satya, Ponirul Ponmanickam \\ Department of Microbiology, Ayya Nadar Janaki Ammal College (Autonomous), India
}

Copyright (C) 2016 by authors, all rights reserved. Authors agree that this article remains permanently open access under the terms of the Creative Commons Attribution License 4.0 International License

\begin{abstract}
Seaweed sample was collected from tide pools and rock surfaces in theKanyakumari coastal region. The bacterial isolate was identified based on the morphological and cultural characteristics. The effect of different $\mathrm{pH}$ on alginase production by Bacillus sp. is at $\mathrm{pH} 8.0(10.9 \pm 0.34$ $\mathrm{IU} / \mathrm{ml})$. Among the various temperatures tested, maximum alginase production was recorded in $40^{\circ} \mathrm{C}(15.9 \pm 0.39$ $\mathrm{IU} / \mathrm{ml})$. The effect of metal ions tested at calcium chloride $(32.41 \pm 0.47 \mathrm{IU} / \mathrm{ml})$. Sodium alginate matrix was increased gradually up to $24 \mathrm{hrs}(0.53 \pm 0.012 \mathrm{IU} / \mathrm{ml})$. Agar-Agar matrix was better steadily up to $24 \mathrm{hrs}(0.6 \pm 0.017 \mathrm{IU} / \mathrm{ml})$. Gelatin matrix was increased gradually up to $24 \mathrm{hrs}(0.37 \pm 0.10$ $\mathrm{IU} / \mathrm{ml}$ )There are four variables used for the factorial analysis including $\mathrm{pH}$, temperature, alginate and ammonium chloride namely $\mathrm{X} 1, \mathrm{X} 2, \mathrm{X} 3$ and $\mathrm{X} 4$ respectively. There was a considerable variation in the alginase production depending on the four chosen variables. The maximum alginase production of $36.4 \mathrm{IU} / \mathrm{ml}$ was achieved by RSM (CCD).
\end{abstract}

Keywords Alginase, Immobilization Matrix, RSM

\section{Introduction}

Alginate is such an important component of the outer surface in the context of chronic $P$. aeruginosa lung infections in Cystic fibrosis. The researchers that first identified alginate on the surface of $P$. aeruginosa recognized enzymes that degrade this polysaccharide [1].Cystic fibrosis (CF) is the most common fatal genetic disease among the Caucasian population producing a multisystem disorder. CF is characterized chiefly by chronic airways obstruction and infection and by exocrine pancreatic in sufficiency with its effects on gastrointestinal function, nutrition, growth, maturation and reproduction [2]. This disease is the most common life-threatening genetic trait in Caucasian populations of European ancestry [3].

The alginic acid salt form alginate can be degraded by radiation or thermal treatment [4]. Biological degradation, on the other hand, is generally conducted by an alginate lyase (EC 4.2.2.3) that acts on the 4-O-linked glycosidic linkage of alginate [5]. Alginate lyases have been isolated from a wide range of organisms, including algae, marine invertebrates, and marine and terrestrial microorganisms [6]. Most alginate degrading bacteria were originally found to be closely associated with marine algae or mollusks. Alginate lyases, also known as alginases or alginate depolymerases, catalyze the degradation of alginate by a [beta] elimination mechanism. Although all lyases perform essentially the same depolymerization action on alginate, each enzyme is defined by its individual characteristics and its preference for the glycolytic bond connecting $\mathrm{M}$ and $\mathrm{G}$ monomers. Although most organisms produce a single alginate lyase with defined substrate specificity, some marine animals and bacterial strains produce two or more enzymes [6].

Alginate can restrict the diffusion of certain antibiotics into the cell and can also inhibit several of the host's major antibacterial defense mechanisms, making it very difficult for $\mathrm{CF}$ patients to clear mucoid $P$. aeruginosa from their lungs [7].Alginate lyases have been identified in a variety of bacteria, including marine bacteria [8].

Alginate oligosaccharides are depolymerization products of alginate by alginate lyases or physicochemical method. They have attracted considerable attention because of their applications in the food industry as growth promoters for plants and as therapeutic agents i.e., anticoagulants, tumor inhibitors and suppression of $\operatorname{IgE}[9,10]$. The alginate lyase are still being developed with poor sources, narrow substrate specificity and low enzyme activity and limit the generation of novel alginate oligosaccharides. The present study reveals that the selected isolates shows high enzyme activity and wide substrate specificity and also expand the potential applications of alginate lyases.

\section{Materials and Methods}

\subsection{Collection and Processing of the Sample}

Seaweed Sargassum wightii sample was collected form 
tide pools and rock surfaces in the Kanyakumari coastal region.Sargassum wightii sample was collected using sterile scalpel and transferred to sterile bottle. Then the sample was used for further microbiological analysis.

\subsection{Screening Alginase Producing Bacteria}

Screening plates with a medium composed of $0.5 \mathrm{~g} \mathrm{NaCl}_{2}$ $1 \mathrm{~g}\left(\mathrm{NH}_{4}\right)_{2} \mathrm{SO}_{4}, 0.5 \mathrm{~g} \mathrm{KH}_{2} \mathrm{PO}_{4}, 1.5 \mathrm{~g} \mathrm{~K}_{2} \mathrm{HPO}_{4}, 0.2 \mathrm{~g} \mathrm{MgSO}_{4}$, and sodium alginate $10 \mathrm{~g}$ The plates were then incubated at $37^{\circ} \mathrm{C}$ for $24 \mathrm{hrs}$ to form detectable colonies [11].

\subsection{Alginase Assay}

The culture was centrifuged at $10000 \mathrm{rpm}$ for $10 \mathrm{mins}$ at $4^{\circ} \mathrm{C}$. The supernatant was used as crude enzyme source for alginase assay. A solution of $0.6 \mathrm{~g}$ sodium alginate was dissolved in phosphate buffer was used as the substrate. The reaction was performed by adding $1 \mathrm{ml}$ substrate to $1 \mathrm{ml}$ enzyme. Incubation was performed in a water bath at $37^{\circ} \mathrm{C}$ for 20 mins. The reaction was terminated by addition of $1 \mathrm{ml}$ of DNS reagent and tubes were kept at boiling water bath for 10 mins. After cooling the tubes at room temperature, $1 \mathrm{ml}$ of distilled water was added in each tube. The intensity of the colour was read at $540 \mathrm{~nm}$ in UV-Vis spectrophotometer (Systronics, 119). Standard curve was performed with glucose solution. One unit of enzyme activity was defined as the amount of enzyme required for under assay condition. Enzyme activity was expressed in International units [11].Alginase activity was calculated using this formula:

$$
\mathrm{IU} / \mathrm{ml}=\text { concentration of glucose } / 1 \times 30 \times 0.180
$$

\subsection{Acetone Precipitation}

The protein precipitation, double the amount of acetone was added to the culture supernatant solution and the solution was left overnight at $4^{\circ} \mathrm{C}$, the supernatant was removed and pellet of precipitated protein was kept and dried at laboratory temperature [12].

\subsection{Effect of $\mathrm{pH}$}

The effect of $\mathrm{pH}$ on alginase activity and stability were determined individually for crude alginase obtained from Bacillus sp. [10].

\subsection{Effect of Temperature}

The effect of temperature on the stability of alginase was determined in the temperature at $\mathrm{pH} 9$ for $30,60,90,120$, 150 and 180 mins [10].

\subsection{Effect of Metal Ions}

The effect of various metal ions on alginase activity and stability were determined individually for crude alginase of Bacillus sp. [13].

\subsection{Effect of Various Surfactants on Alginase Activity and Stability}

The effect of surfactants on the activity of crude alginase was determined by pre-incubating the enzyme in the presence of Triton X-100 (1\%), Tween-20 (1\%), Tween-80(1\%), SDS $(0.1 \%)$, Poly ethylene glycol $\left(0.1 \%\right.$ ), for 30 mins at $40^{\circ} \mathrm{C}$ before adding the substrate and subsequently relative alginase activities were measured at optimum temperature and alginase activity were determined. To determine surfactants stability, the enzyme was pre-incubated at $40^{\circ} \mathrm{C}$ for $24 \mathrm{hrs}$ at $\mathrm{pH}$ 9. The effect of different surfactants on alginase activity and stability were determined individually for crude alginase of Bacillus sp [10].

\subsection{Silver Staining}

Transfer the gel into fixer containing the following mixture. Water: Acetone: TCA: Formaldehyde keeps in rocker for 5 mins. Wash the gel with water for 3 times $(10 \mathrm{sec}$ wash) keep in $50 \%$ acetone for 5 mins. Add $100 \mu \mathrm{l}$ of $\mathrm{Na}_{2} \mathrm{~S}_{2} \mathrm{O}_{3}(0.1 \mathrm{~g} / \mathrm{ml})$. Wash the gel 3 times with millique water. Add $600 \mathrm{ml}$ of formaldehyde and $800 \mathrm{ml}$ of silver nitrate $(0.2 \mathrm{~g} / \mathrm{ml})$ in $60 \mathrm{ml}$ of millique water and keep the gel 3 times with millique water. Add developer to the gel containing following $1.2 \mathrm{~g}$ of $\mathrm{Na}_{2} \mathrm{CO}_{3}, 25 \mathrm{ml}$ of $\mathrm{Na}_{2} \mathrm{CO}_{3}(0.1 \mathrm{~g} / \mathrm{ml}), 25 \mathrm{ml}$ of formaldehyde in $\mathrm{ml}$ of millique water. Develop for 5-10 seconds until bands start appearing. Stop the reaction with $1 \%$ Acetic acid [14]

\subsection{Immobilization Studies on Bacillus sp.}

\subsubsection{Preparation of Cell Suspension}

Bacillus sp. was grown in the production medium. Cells after incubation were harvested by centrifugation at 10,000 rpm for 15 mins. Cells pellet were washed with $2 \%(w / v)$ $\mathrm{KCl}_{2}$ solution, followed by $0.9 \%(\mathrm{w} / \mathrm{v}) \mathrm{NaCl}_{2}$ solution and sterile distilled water subsequently. Finally cells were suspended in $\mathrm{NaCl}_{2}$ solution and stored at $4^{\circ} \mathrm{C}$ for further studies.

\subsubsection{Immobilization of Whole Cells in Sodiumalginate}

Cells were harvested after 24 hours by centrifugation at $10000 \mathrm{rpm}$ for 15 mins. Sodium alginate solution for this different concentration of sodium alginate $(5,5.5,6,6.5$ and $7 \%$ ) was prepared in boiling water and autoclaved at $121^{\circ} \mathrm{C}$ for 15 mins. Both alginate slurry and cell suspension (2 $\mathrm{ml} / 10 \mathrm{ml}$ of alginate) were mixed and stirred for 10 minutes to get a uniform mixture. The slurry was taken into a sterile syringe and added drop wise into $0.2 \mathrm{M} \mathrm{CaCl}_{2}$ solution from $5 \mathrm{~cm}$ height and kept for curing at $4^{\circ} \mathrm{C}$ for $1 \mathrm{hrs}$. The cured beads (mean diameter of $2 \mathrm{~mm}$ ) were washed 4 times with sterile distilled water after being used as inoculum for alginase production. Approximately 50 beads were transferred to $50 \mathrm{ml}$ production medium with an agitation of $120 \mathrm{rpm}$ at $40^{\circ} \mathrm{C}[15]$. 


\subsubsection{Immobilization of Whole Cells in Agar-agar}

The various concentrations of agar-agar were dissolved in $18 \mathrm{ml}$ of $0.9 \%$ sodium chloride solution to get final concentration of $2 \%$ and sterilized by autoclaved at $121^{\circ} \mathrm{C}$ for 15 minutes. Cell suspension $(2 \mathrm{ml})$ was added to molten agar-agar maintained at $40^{\circ} \mathrm{C}$. Then it was shaken well for few seconds (without forming foam) poured into sterile petriplates and allowed to solidify. The solidified agar block was cut with well puncture $(10 \mathrm{~mm})$ added to sterile $0.1 \mathrm{M}$ phosphate buffer $(\mathrm{pH} 7)$ and kept in the refrigerator $(1 \mathrm{~h})$ for curing. After curing, the agar blocks were washed 4 times with sterile distilled water, after being used as inoculum for alginase production. Approximately 30 blocks were transferred to $50 \mathrm{ml}$ production medium with an agitation of $120 \mathrm{rpm}$ at $40^{\circ} \mathrm{C}[15]$.

\subsubsection{Immobilization of Whole Cells in Gelatin}

Five milliliters $(0.06 \%$ DCW) of cell suspension was added to $15 \mathrm{ml}$ of poured into a sterile Petri dish. The gel was over layered with $10 \mathrm{ml}$ of $5 \%$ glutaraldehyde for hardening at $30^{\circ} \mathrm{C}$ The resulting block was cut into small-size cubes $(4 \mathrm{~mm})$ and the cubes were washed thoroughly with sterile distilled water for complete removal of excess glutaraldehyde, after being used as inoculum for alginase production. Approximately 30 blocks were transferred to $50 \mathrm{ml}$ production medium with an agitation of $120 \mathrm{rpm}$ at $40^{\circ} \mathrm{C}[15]$.

\subsubsection{Statistical Optimization of Nutrient Supplements (CCD AND RSM)}

From the optimized nutrient composition for Bacillus sp. growth rate, the effect of the $\mathrm{pH}$, temperature, carbon source (Alginate) and nitrogen source (Ammonium chloride) level were studied using Central Composite Design (CCD) [16].

\section{Results}

\subsection{Effect of $\mathbf{p H}$}

The effect of $\mathrm{pH}$ on alginase stability was determined in $\mathrm{pH} 9$ with various incubation times in mins ranging from 30-180 mins. Maximum alginase activity of $0.77 \pm 0.014$ $\mathrm{IU} / \mathrm{ml}$ was recorded in $\mathrm{pH} 9$ at 30 mins. The enzyme activity was decreased to $0.48 \pm 0.013 \mathrm{IU} / \mathrm{ml}$ in $\mathrm{pH} 9$ at $180 \mathrm{mins}$ was shown in fig. 1.

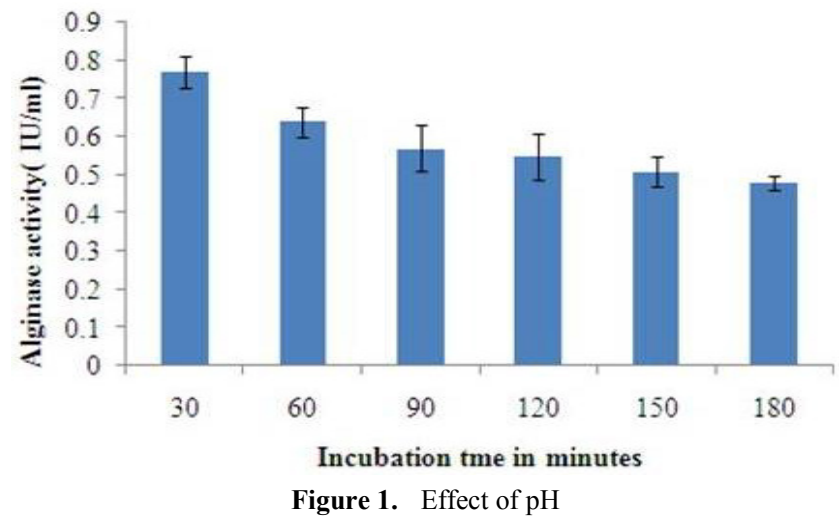

\subsection{Effect of Temperature}

The effect of temperature on the stability of crude alginase was determined in $40^{\circ} \mathrm{C}$ with various incubation times in mins range from 30-180 mins. Maximum alginase activity of $0.82 \pm 0.017 \mathrm{IU} / \mathrm{ml}$ was recorded at 30 minutes. The enzyme activity was decreased to $0.24 \pm 0.011 \mathrm{IU} / \mathrm{ml}$ at 180 minutes. The $\mathrm{pH}$ stability of enzyme was measured by the standard assay method with glucose is shown in fig. 2 .

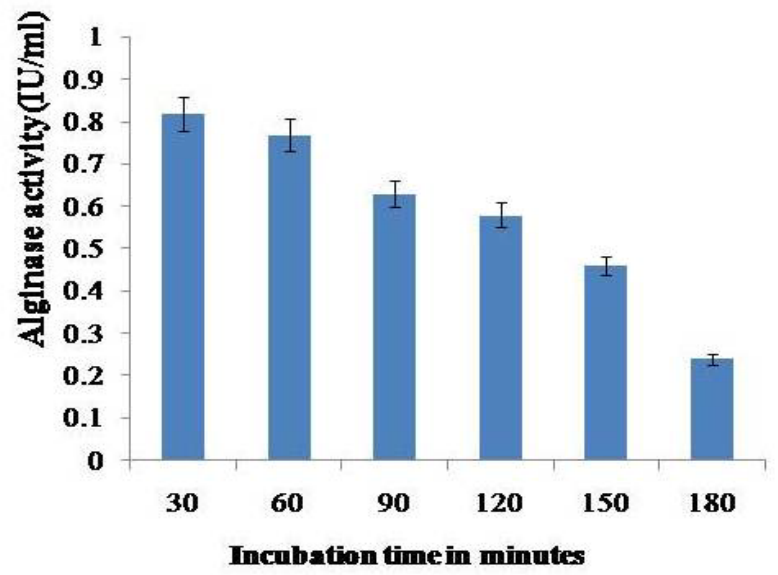

Figure 2. Effect of temperature

\subsection{Effect of Various Metal Ions}

The crude alginase was pre-incubated at $40^{\circ} \mathrm{C}$ for $30 \mathrm{mins}$ at different concentration of the metal ions. Maximum alginase activity of $0.81 \pm 0.016 \mathrm{IU} / \mathrm{ml}$ was recorded at calcium chloride. Minimum alginase activity of $0.24 \pm 0.009$ $\mathrm{IU} / \mathrm{ml}$ was recorded at potassium chloride is shown in fig. 3 . 


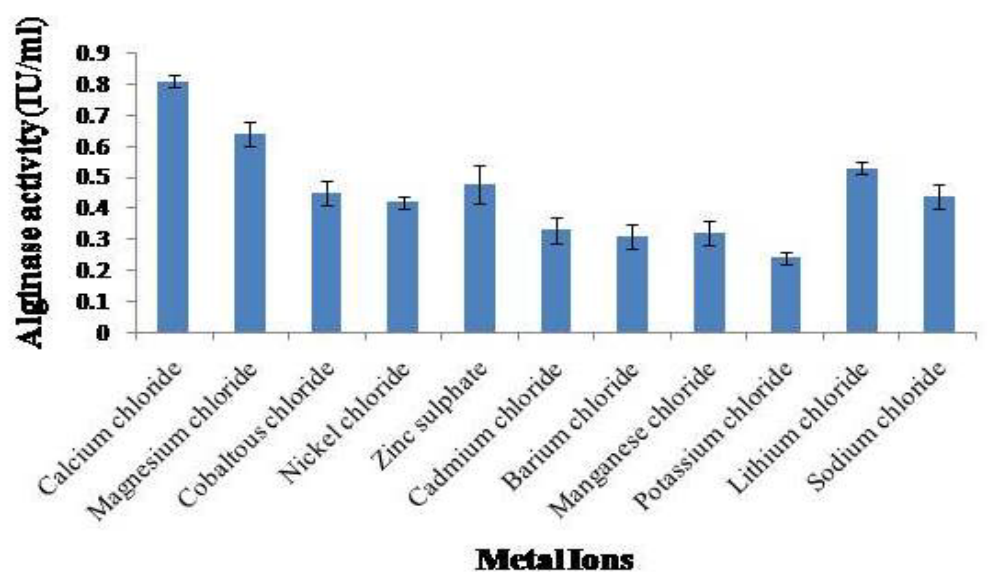

Figure 3. Effect of various metal ions on alginase activity

\subsection{Effect of Different Surfactants}

The relative activity of alginase was decreased with increased in concentration of surfactants and also by time of exposure. Maximum alginase activity of $0.51 \pm 0.012 \mathrm{IU} / \mathrm{ml}$ was recorded at sodium dodecyl sulphate. Minimum alginase activity of $0.2 \pm 0.008 \mathrm{IU} / \mathrm{ml}$ was recorded at triton X-100 is shown in Fig.4.

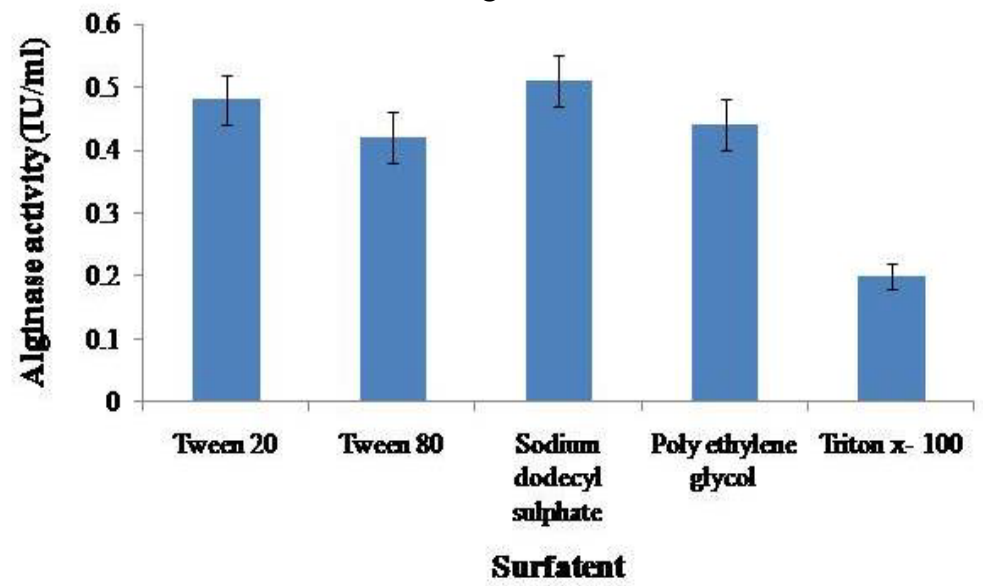

Figure 4. Effect of different surfactants on alginaseactivity

\subsection{Silver Staining for Crude Alginase}

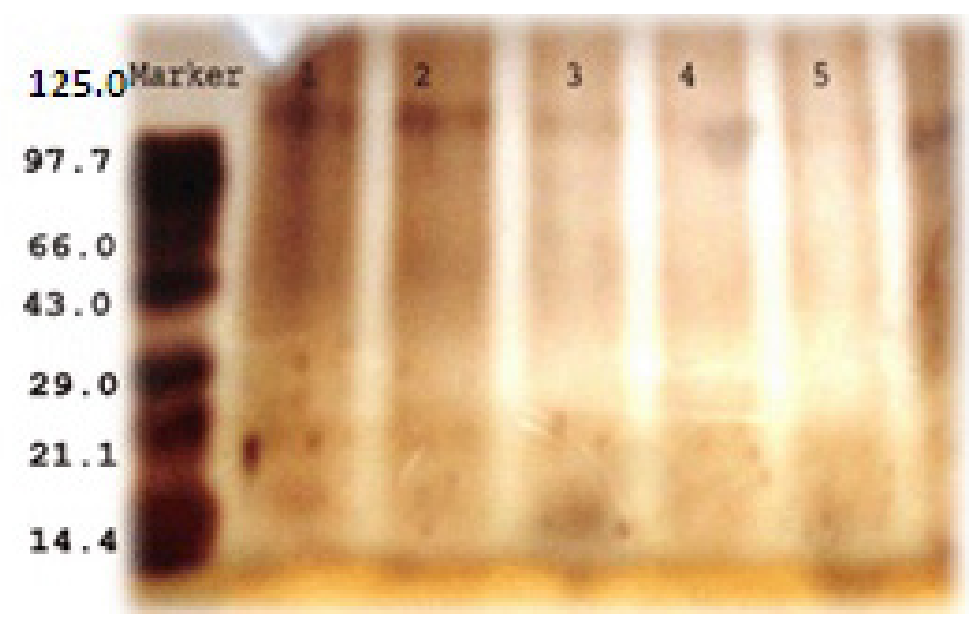

Figure 5. Silver staining for crude alginase

Crude protein and protein of the pooled fractions from the gel filtration that contained alginase activity after electrophoresis through a sodium dodecyl sulfate-polyacrylamide gel and visualization by silver staining, although a protein band with apparent molecular weight of $125 \mathrm{KDa}$ is shown in Fig. 5. 


\subsection{Immobilization Studies for Crude Alginase}

\subsubsection{Production of Alginase by Immobilized Cells of Bacillus sp. in Sodium Alginate}

Sodium alginate matrix was increased gradually up to 24hrs of incubation after which there were no appreciable changes. The enzyme production reached maximum $(0.53 \pm 0.012 \mathrm{IU} / \mathrm{ml})$ by 48 hrs is shown in Fig. 6 and plate 1 .

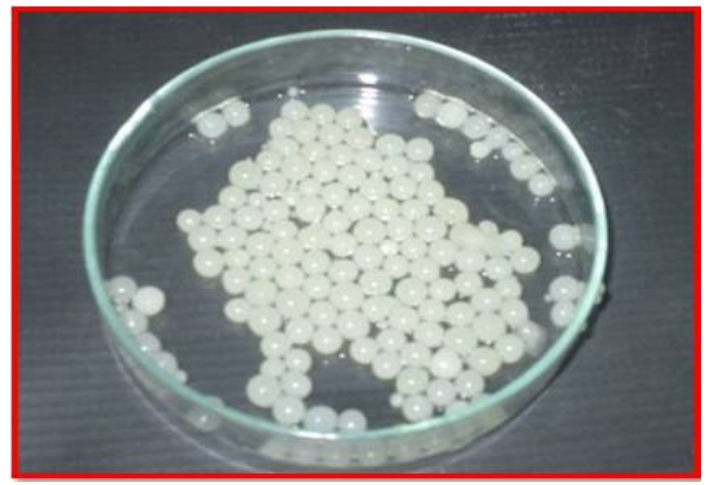

Plate 1. Production of alginase by Immobilized cells in sodium alginate

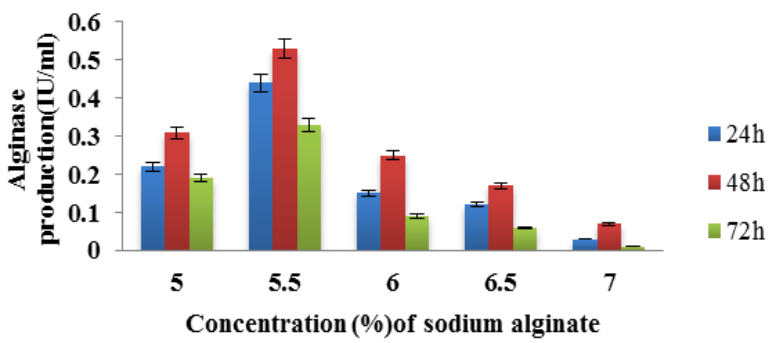

Figure 6. Immobilization of alginase producing Bacillus sp. using sodium alginate

\subsubsection{Production of Alginase by Immobilized Cells Using Agar Agar}

Agar agar matrix was better steadily up to $24 \mathrm{hrs}$ of incubation after which there was no appreciable change. The enzyme production reached maximum level $(0.6 \pm 0.017$ $\mathrm{IU} / \mathrm{ml}$ ) by $48 \mathrm{hrs}$ with $4 \%$. On further incubation, enzyme production gradually decreased $(0.09 \pm 0.002)$ in $7 \%$ is shown in Fig. 7 and plate 2.

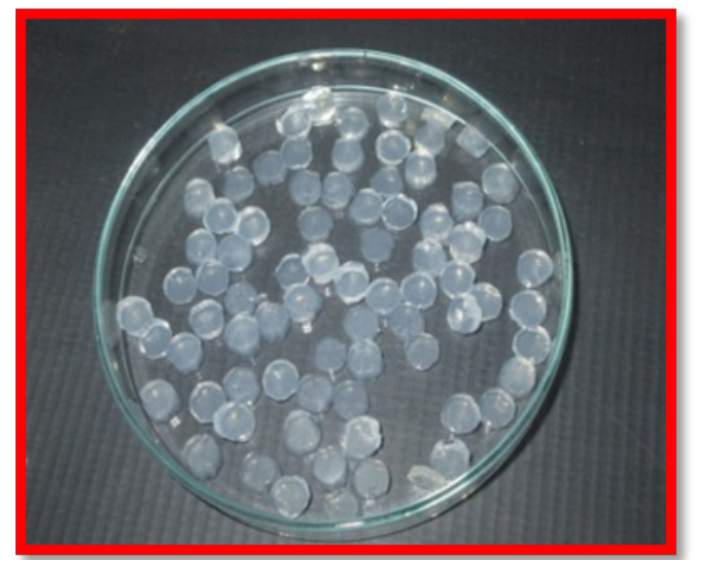

Plate 2. Production of alginase by Immobilized Cells Using Agar agar

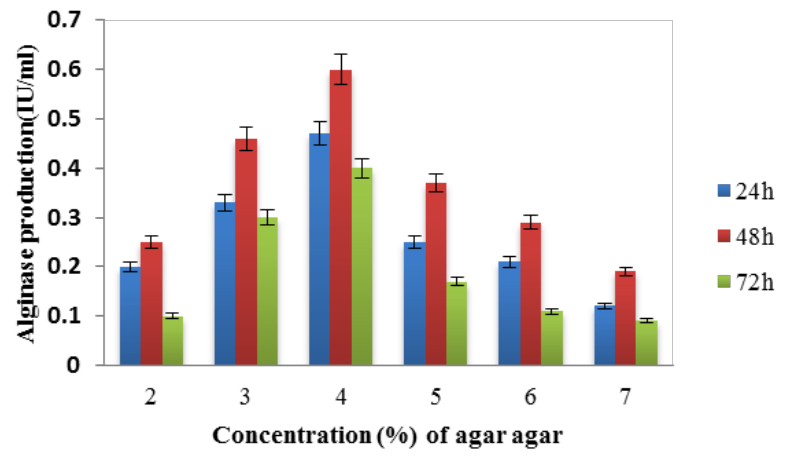

Figure 7. Immobilization of alginase producing Bacillus sp. by Agar agar

\subsubsection{Production of Alginase by Immobilized Cells Using Gelatin}

Gelatin matrix was increased gradually up to $24 \mathrm{hrs}$ of incubation after which there was no appreciable change. The enzyme production reached maximum level in $(0.37 \pm 0.10$ $\mathrm{IU} / \mathrm{ml}$ ) by $48 \mathrm{hrs}$ with $20 \%$. On further incubation, enzyme production gradually decreased $(0.19 \pm 0.07)$ in $5 \%$ is shown in Fig. 8 and plate 3 .

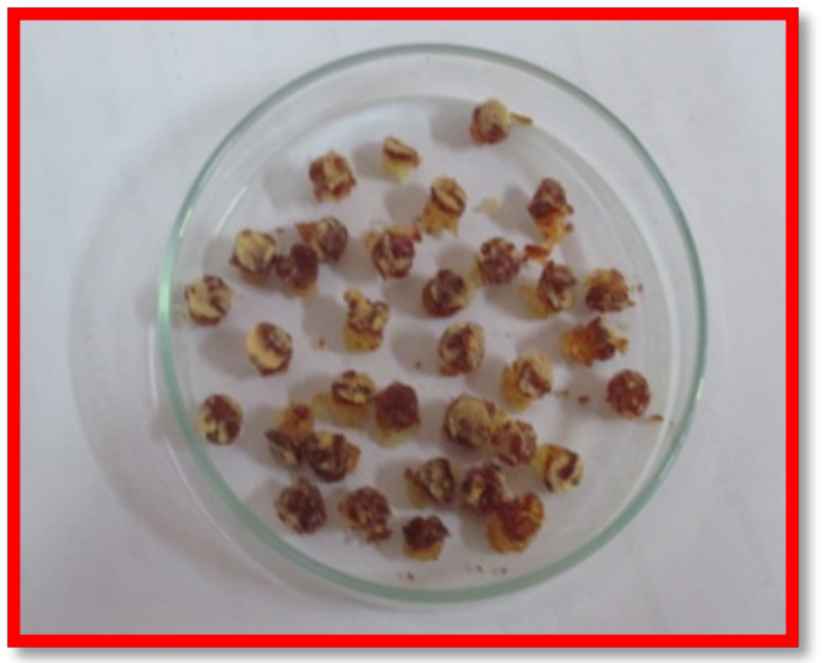

Plate 3. Production of Alginase by Immobilized Cells Using gelatin

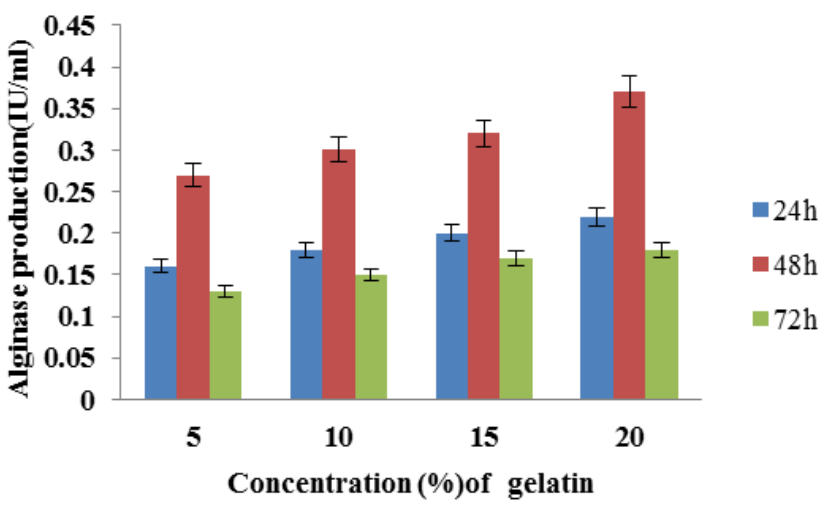

Figure 8. Immobilization of alginase producing Bacillu ssp. using gelatin 


\subsection{Statistical Studies for Crude Alginase Producing Bacillus sp. Using Central Composite Design}

Table 1 shows the five levels of variables chosen for trials in CCD. Response surface methodology (RSM) was used to optimize cultivation conditions for Alginase production, 30 experimental runs with different combinations of four factors and five levels were carried out (Table 2). The variables used for the factorial analysis were $\mathrm{pH}$, temperature, Alginate and ammonium chloride, named $\mathrm{X} 1, \mathrm{X} 2, \mathrm{X} 3$ and $\mathrm{X} 4$ this design, respectively. The effects of the four independent variables on alginase production and the experimental response are along with the predicted response. The interaction effects of variables on alginase production were studied by plotting $3 \mathrm{D}$ surface curves against any two independent variables, while keeping another variable at its central (0) level.

The predicted values from the regression equation closely agreed with that obtained from experimental values. Validation of the experimental model was tested by carrying out the batch experiment under optimal operation conditions. Three repeated experiments were performed and the results are compared. The alginase obtained from experiments was very close to the actual response predicted by the regression model, which proved the validity of the model. At these optimized conditions the maximum alginase production was found to be $36.4 \mathrm{IU} / \mathrm{ml}$. The results show a close concordance between the expected and obtained activity level (Fig.9 and 10a, b, c, d, e and f).

Table. 1. Observed and predicted responses for the experiments performed using CCD design for alginase production

\begin{tabular}{|c|c|c|c|c|c|c|c|}
\hline Std & Run & $\begin{array}{c}\text { Facter:1 } \\
\mathbf{A}: \mathbf{P}^{\mathrm{H}}\end{array}$ & $\begin{array}{c}\text { Facter:2 } \\
\text { B:Temperature }\end{array}$ & $\begin{array}{c}\text { Facter:3 } \\
\text { C:Alginate }\end{array}$ & $\begin{array}{c}\text { Facter:4 } \\
\text { D:Ammonium } \\
\text { chloride }\end{array}$ & $\begin{array}{c}\text { Actual } \\
\text { alginase } \\
\text { IU/ml }\end{array}$ & $\begin{array}{c}\text { Predicated } \\
\text { Alginase } \\
\text { IU/ml } \\
\end{array}$ \\
\hline 12 & 1 & 9 & 50 & 0.5 & 0.75 & 32.5 & 32.8 \\
\hline 9 & 2 & 7 & 30 & 0.5 & 0.75 & 34.3 & 34.2 \\
\hline 24 & 3 & 8 & 40 & 1 & 1 & 31.9 & 32.1 \\
\hline 28 & 4 & 8 & 40 & 1 & 0.5 & 36.4 & 36.4 \\
\hline 7 & 5 & 7 & 50 & 1.5 & 0.25 & 33.5 & 33.2 \\
\hline 5 & 6 & 7 & 30 & 1.5 & 0.25 & 34.8 & 34.3 \\
\hline 30 & 7 & 8 & 40 & 1 & 0.5 & 36.4 & 36.4 \\
\hline 18 & 8 & 10 & 40 & 1 & 0.5 & 33.4 & 33.4 \\
\hline 23 & 9 & 8 & 40 & 1 & 0 & 31.6 & 31.8 \\
\hline 25 & 10 & 8 & 40 & 1 & 0.5 & 36.4 & 36.4 \\
\hline 6 & 11 & 9 & 30 & 1.5 & 0.25 & 33.5 & 33.1 \\
\hline 17 & 12 & 6 & 40 & 1 & 0.5 & 34.7 & 35.1 \\
\hline 3 & 13 & 7 & 50 & 0.5 & 0.25 & 32.8 & 32.8 \\
\hline 15 & 14 & 7 & 50 & 1.5 & 0.75 & 34.4 & 33.9 \\
\hline 27 & 15 & 8 & 40 & 1 & 0.5 & 36.4 & 36.4 \\
\hline 2 & 16 & 9 & 30 & 0.5 & 0.25 & 32.8 & 33.0 \\
\hline 4 & 17 & 9 & 50 & 0.5 & 0.25 & 32.5 & 32.2 \\
\hline 19 & 18 & 8 & 20 & 1 & 0.5 & 32.5 & 32.8 \\
\hline 22 & 19 & 8 & 40 & 2 & 0.5 & 34.4 & 35.3 \\
\hline 16 & 20 & 9 & 50 & 1.5 & 0.75 & 34.3 & 33.9 \\
\hline 8 & 21 & 9 & 50 & 1.5 & 0.25 & 33.2 & 33.1 \\
\hline 29 & 22 & 8 & 40 & 1 & 0.5 & 36.4 & 36.4 \\
\hline 20 & 23 & 8 & 60 & 1 & 0.5 & 31.7 & 31.9 \\
\hline 10 & 24 & 9 & 30 & 0.5 & 0.75 & 32.7 & 32.6 \\
\hline 11 & 25 & 7 & 50 & 0.5 & 0.75 & 33.4 & 33.3 \\
\hline 1 & 26 & 7 & 30 & 0.5 & 0.25 & 34.8 & 34.7 \\
\hline 13 & 27 & 7 & 30 & 1.5 & 0.75 & 34.1 & 33.9 \\
\hline 14 & 28 & 9 & 30 & 1.5 & 0.75 & 33.2 & 32.9 \\
\hline 26 & 29 & 8 & 40 & 1 & 0.5 & 36.4 & 36.4 \\
\hline 21 & 30 & 8 & 40 & 0 & 0.5 & 35 & 34.6 \\
\hline
\end{tabular}


Table 2. Analysis of variance (ANOVA) for quadratic model for alginase production

\begin{tabular}{|c|c|c|c|c|c|}
\hline Source & Sum of Squares & DF & Mean Square & F Value & P-Value Prob $>$ F \\
\hline Model & 64.56 & 14 & 4.61 & 27.05 & $<0.0001^{\mathrm{C}}$ \\
\hline A-pH & 4.17 & 1 & 4.17 & 24.45 & 0.0002 \\
\hline B-Temperature & 1.13 & 1 & 1.13 & 6.61 & $0.0213^{\mathrm{C}}$ \\
\hline C-Alginate & 0.67 & 1 & 0.67 & 3.91 & 0.0666 \\
\hline $\begin{array}{c}\text { D-Ammonium } \\
\text { chloride }\end{array}$ & 0.11 & 1 & 0.11 & 0.63 & $0.4412^{\mathrm{C}}$ \\
\hline $\mathrm{AB}$ & 1.10 & 1 & 1.10 & 6.47 & $0.0225^{\mathrm{C}}$ \\
\hline $\mathrm{AC}$ & 0.30 & 1 & 0.30 & 1.77 & $0.2027^{\mathrm{C}}$ \\
\hline $\mathrm{AD}$ & 0.010 & 1 & 0.010 & 0.059 & 0.8119 \\
\hline $\mathrm{BC}$ & 0.64 & 1 & 0.64 & 3.75 & 0.0717 \\
\hline $\mathrm{BD}$ & 1.10 & 1 & 1.10 & 6.47 & 0.0225 \\
\hline $\mathrm{CD}$ & 0.063 & 1 & 0.063 & 0.37 & 0.5539 \\
\hline $\mathrm{A} 2$ & 7.44 & 1 & 7.44 & 43.65 & $<0.0001^{\mathrm{C}}$ \\
\hline B2 & 27.89 & 1 & 27.89 & 163.62 & $<0.0001^{\mathrm{C}}$ \\
\hline $\mathrm{C} 2$ & 3.52 & 1 & 3.52 & 20.66 & $0.0004^{\mathrm{C}}$ \\
\hline $\mathrm{D}^{2}$ & 32.94 & 1 & 32.94 & 193.25 & $<0.0001^{\mathrm{C}}$ \\
\hline Residual & 2.56 & 15 & 0.17 & & \\
\hline Lack of Fit & 2.56 & 10 & 0.26 & & \\
\hline Pure Error & 0.000 & 5 & 0.000 & & \\
\hline Core Total & 67.11 & 29 & & & \\
\hline
\end{tabular}

$\mathrm{R}^{2}=0.9594 ; \mathrm{Adj}^{2}=0.9216$; C.V. $\%=2.92$; ${ }^{\mathrm{C}}$ model terms are significant.

Design-Expert@ Software Alginase

Color points by value of Alginase:

36.4

31.6

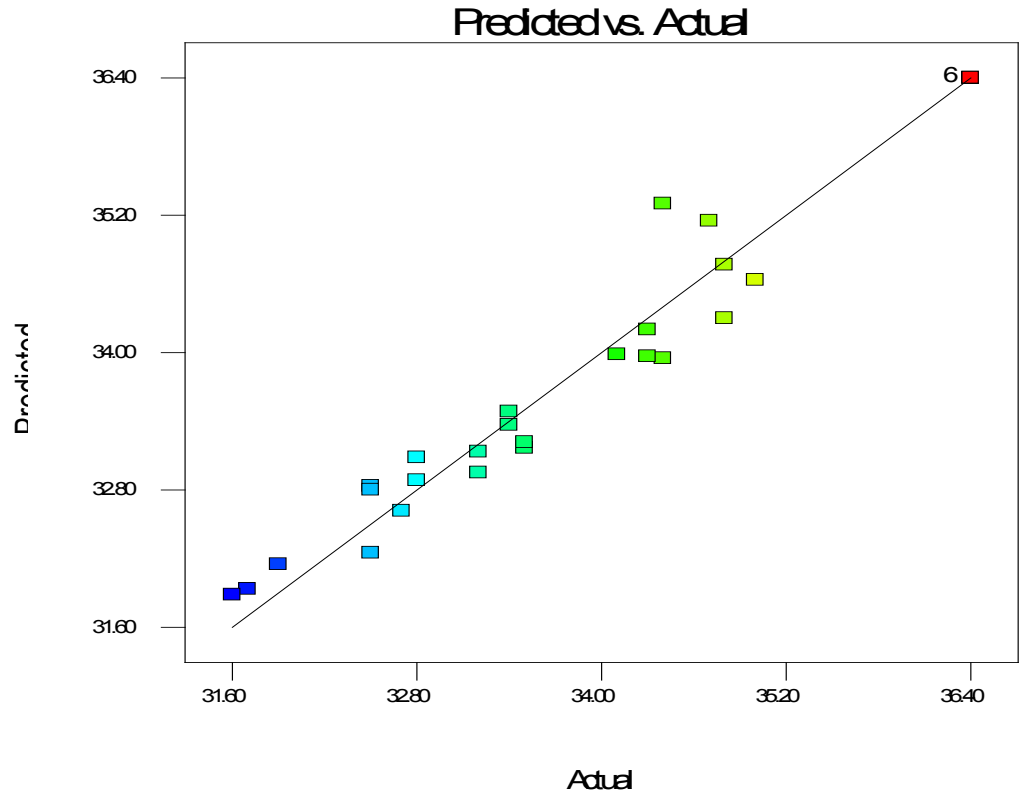

Figure 9. Predicted response versus actual values selected bacteria for alginase production 
Design-Expert@ Software

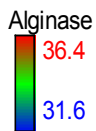

$\mathrm{X} 1=\mathrm{A}: \mathrm{pH}$

$\mathrm{X} 2=\mathrm{B}$ : Temperature

Actual Factors

C: Alginate $=1.00$

D: Ammonium chloride $=0.50$

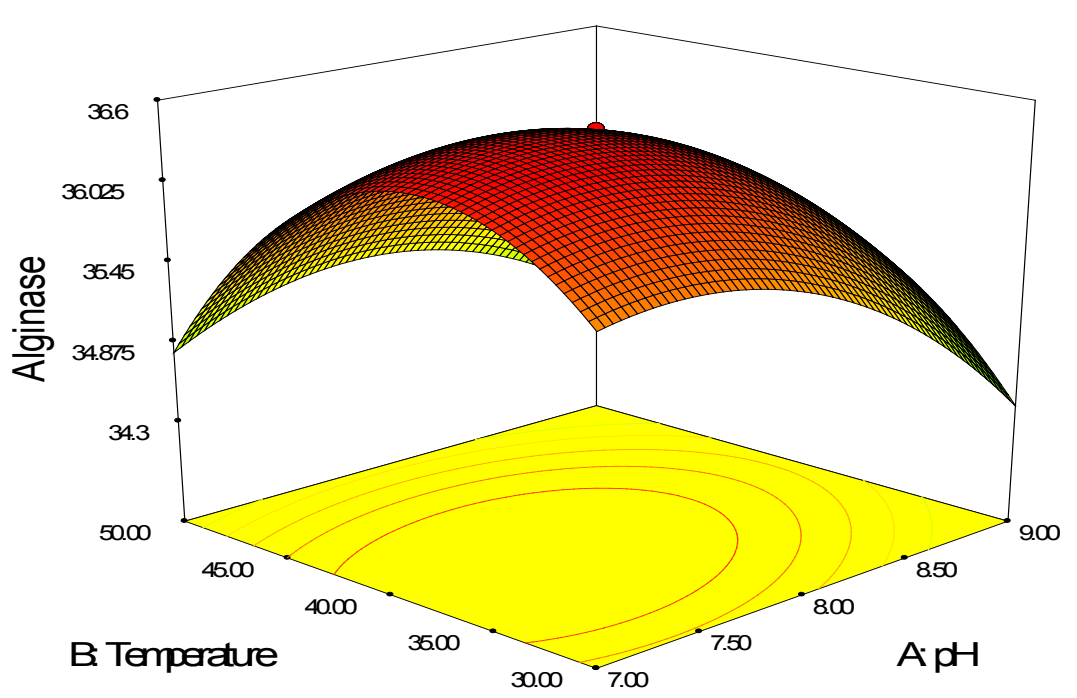

Figure 10a. 3D plot showing the effect of $\mathrm{pH}$ and temperature

Design-Expert® Software

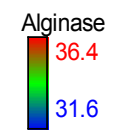

$\mathrm{X} 1=\mathrm{A}: \mathrm{pH}$

$\mathrm{X} 2$ = C: Alginate

Actual Factors

B: Temperature $=40.00$

D: Ammonium chloride $=0.50$

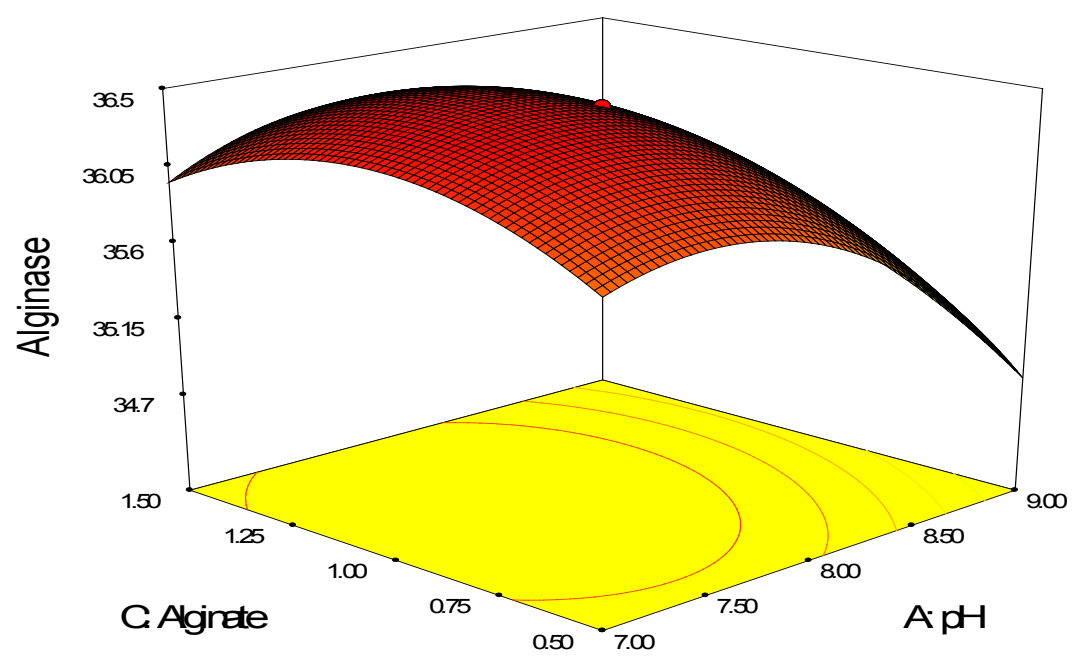

Figure 10b. 3D plot showing the effect of $\mathrm{pH}$ and alginate 
Design-Expert@ Software

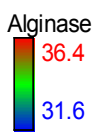

$\mathrm{X} 1$ = C: Alginate

$\mathrm{X} 2$ = D: Ammonium chloride

Actual Factors

A: $\mathrm{pH}=8.00$

B: Temperature $=40.00$

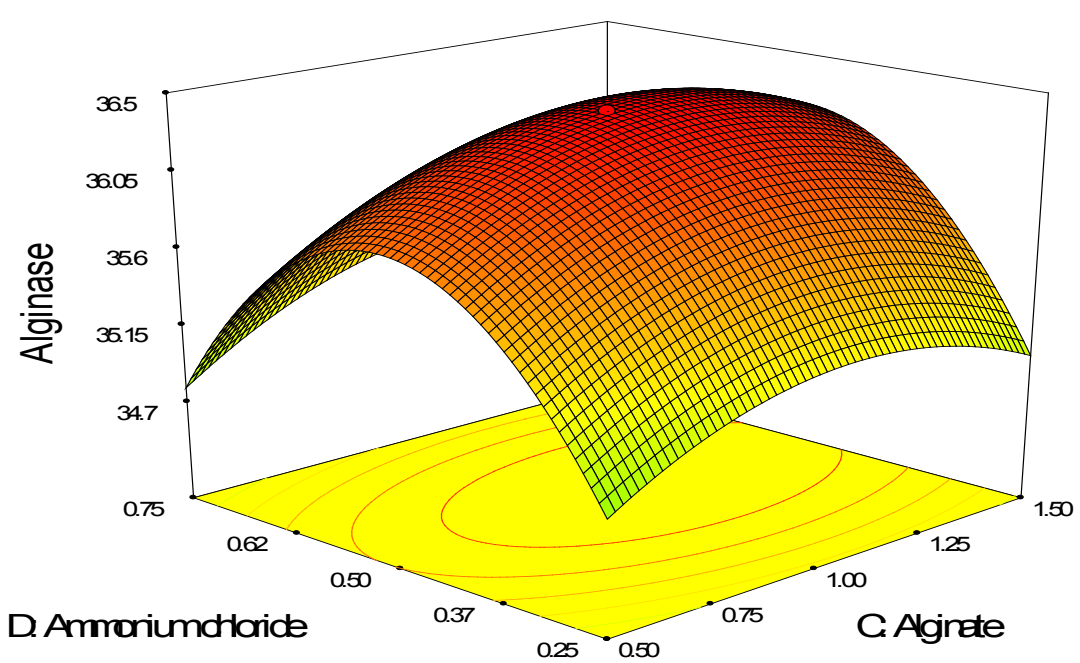

Figure 10c. 3D plot showing the effect of ammonium chloride and alginate

Design-Expert@ Software

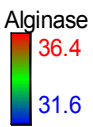

$\mathrm{X} 1=\mathrm{B}:$ Temperature $\mathrm{X} 2$ = C: Alginate

Actual Factors

A: $\mathrm{pH}=8.00$

$\mathrm{D}$ : Ammonium chloride $=0.50$

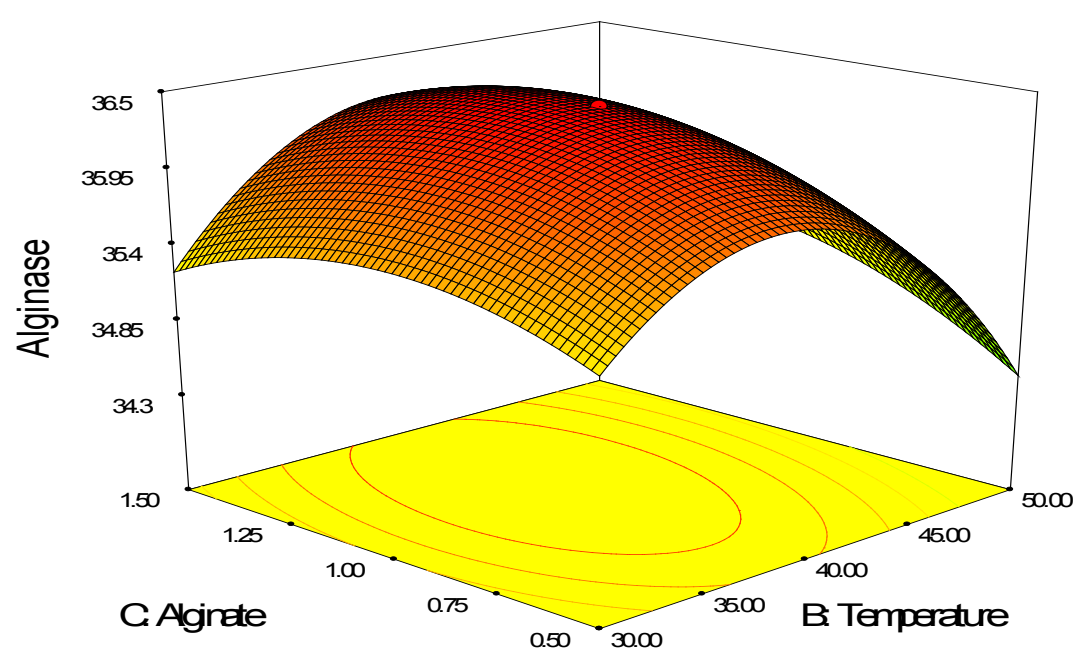

Figure 10d. 3D plot showing the effect of alginate and temperature 
Design-Expert@ Software

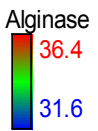

$\mathrm{X} 1=\mathrm{A}: \mathrm{pH}$

$\mathrm{X} 2=\mathrm{D}:$ Ammonium chloride

Actual Factors

B: Temperature $=40.00$

C: Alginate $=1.00$

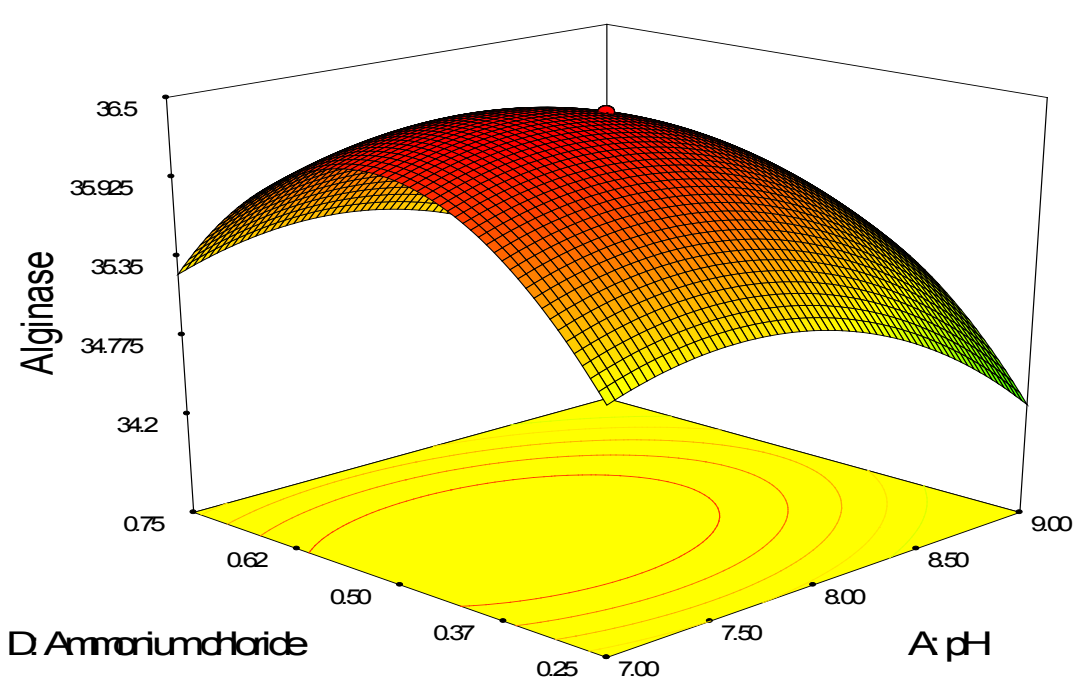

Figure 10e. 3D plot showing the effect of $\mathrm{pH}$ and ammonium chloride

Design-Expert@ Software

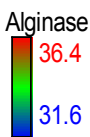

$\mathrm{X} 1=\mathrm{B}:$ Temperature $\mathrm{X} 2$ = D: Ammonium chloride

Actual Factors

$\mathrm{A}: \mathrm{pH}=8.00$

C: Alginate $=1.00$

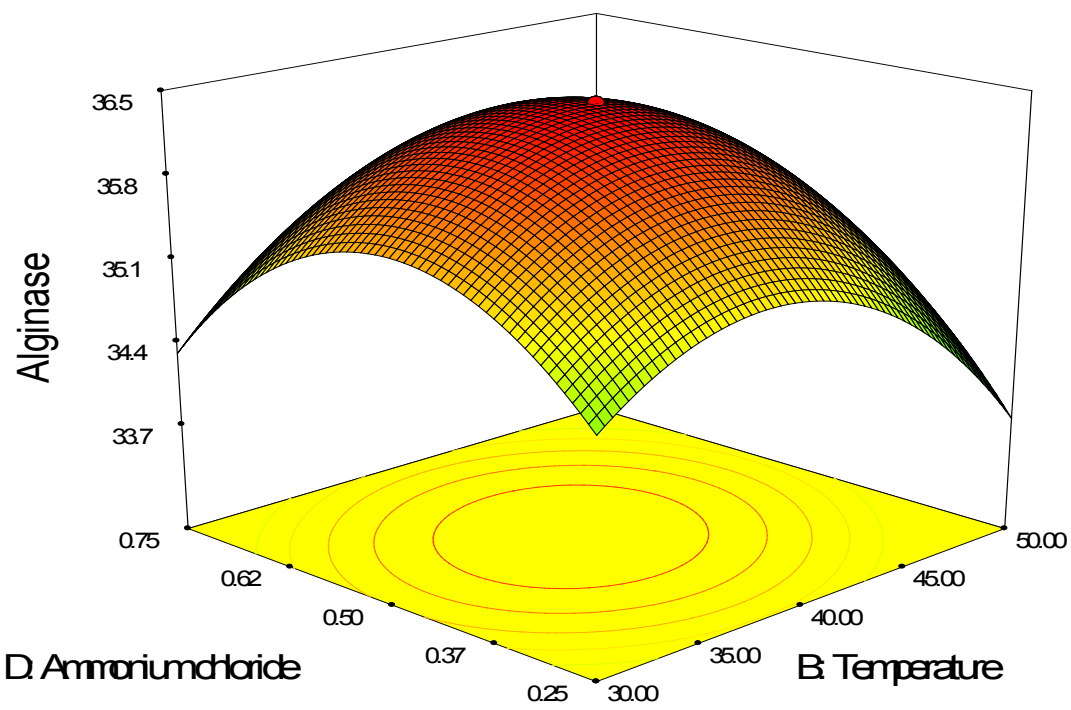

Figure 10f. 3D plot showing the effect of ammonium chloride and temperature

\section{Discussion}

Microorganism about 30 isolates isolated on the minimal medium supplemented with $0.5 \%$ sodium alginate as the sole carbon source were screened. Initially based on the appearance of clearing hydrolytic zone and alginate lyase activities from fermentation culture. It was noted that the $\mathrm{pH}$ of the growth medium is an important parameter for bacterial growth and alginase production. The effect of different $\mathrm{pH}$ values of growth media was also investigated and it was noted that at $\mathrm{pH} 8.0$ the maximum alginase was produced similarly, the effect of different $\mathrm{pH}$ values of growth media was also investigated and it was noted that at $\mathrm{pH} 8.0$ the maximum alginate $(5.71 \mathrm{~g} / 1$ with $6.83 \mathrm{~g} / 1$ of DCM) was produced. Increase or decrease in the medium $\mathrm{pH}$ resulted in the decreased alginate amount [17].

The existing studies the effects of temperature on alginate lyase activity and stability the maximum enzyme activity of the lyase was observed and was stable at $40^{\circ} \mathrm{C}$. Likewise, the lyase possessed approximately $50 \%$ activity after incubation at $45^{\circ} \mathrm{C}$ for 30 mins and was gradually in activated as temperature increased. Further studies on thermal stability at 40,50 and $60^{\circ} \mathrm{C}$ with different time periods demonstrated that the enzyme retained more than $60 \%$ activity after incubation at $40^{\circ} \mathrm{C}$ for $3 \mathrm{hrs}$ [18].

Since, we investigated that the effect of addition of metal 
ions calcium chloride to increase the activity of alginate lyase. Similarly, Hashimoto et al. [19]stated that the effect of metal ions, $\mathrm{pH}$ and temperature on the activity of recombinant oligoalginate lyase of Sphingomonas sp. MJ-3 In order to optimize the saccharification reaction of alginate polymer, Among the metal ions investigated, $\mathrm{K}^{2+}, \mathrm{Mg}^{2+}$, $\mathrm{Mn}^{2+}, \mathrm{Ca}^{2+}$ and $\mathrm{Fe}^{2+}$ displayed activating effects [20].

Cell immobilization is one of the common techniques for increasing the overall cell concentration and productivity. The separation of products from immobilized cells is easier compared with suspended cell systems. Immobilization of cells may allow continuous operation of cultivation processes at high dilution rates. Immobilization is a strategy for protecting cells from shear forces many different techniques for immobilizing cells have been proposed [21].

In this study, the maximum alginase production was observed at $48 \mathrm{hrs}(0.6 \pm 0.017 \mathrm{IU} / \mathrm{ml})$. Similar report was observed by Gauthier et al. [22].The experiment on the effect of immobilization using agar-agar showed that the beads gave 4 to 5 folds higher productions over the free cells. The optimized concentration for this matrix was $7 \%$. This report is in accordance with the earlier reported by Anna et al. [23], it also matched the use of agar-agar entrapped cells of Bacillus circulans ATCC 21783 for cyclo dextrin glucanotransferase production in a fluidized bed reactor led to an enzyme activity $(180 \mathrm{U} / \mathrm{ml})$ after 48 hours of incubation. In the present study, the alginase production was studied from 24 to $72 \mathrm{hrs}$ with immobilized cells gelatin and reached maximum $(0.37 \pm 0.10 \mathrm{IU} / \mathrm{ml})$ at $48 \mathrm{hrs}$.

In other hand, the natural polymers such as agarose, pectin and gelatin were also employed for cell immobilization of the protease production [24]. In the present study, the protease production was studied by using gelatin as a carrier material. The suitable optimizing concentration for the protease production was $6 \%$. Concurrent to this study, gelatin as a carrier material for the production of $\beta$-galactosidase and Penicillin acylase by E. coli was carried out by Ramakrishna and Prakasam [25].

RSM was successful applied to the making of keratinase in Bacillus pumilus AI, whereas the maximum production was $87.73 \mathrm{U} / \mathrm{ml}$ by Zauari et al. [26]. Correspondingly, Sivakumar et al. [27] stated that the maximum keratinase enzyme production $63.01 \mathrm{U} / \mathrm{ml}$ and $60.67 \mathrm{U} / \mathrm{ml}$ was obtained by Bacillus cereus TS1 and Bacillus thuringiensis TS2 respectively. In the present study, it shows that the maximum alginase activity production was $36.4 \mathrm{U} / \mathrm{ml}$. There are four factors namely $\mathrm{pH}$, temperature ammonium chloride and alginate were used for RSM optimization in Bacillus sp. Noticeably Sivakumar et al. [27] stated that the three factors namely $\mathrm{pH}$, temperature and starch were used for RSM optimization in Bacillus cereus TS1 and pH, temperature, mannitol were used for RSM optimization in Bacillus thuriengiensis TS2. The factors like glucose soybean and incubation time were used for RSM optimization by Tiwary and Gupta [28]. The variable used by Xian et al. [29]were feather meal, soy peptone, sodium chloride, potassium chloride and potassium dihydrogen phosphate and the factors like sucrose, yeast extract and feather keratin was used by Matsui et al. [30]As a useful statistical technique, RSM has widely and successfully been applied to the optimization of medium components. At present, large research was aimed to isolate feather degrading microorganism and investigated the characterization of feather degrading enzyme for socioeconomic importance.

\section{Conclusions}

Seaweed sample was collected from tide pools and rock surfaces in the kanyakumari coastal region. The selected isolate was to be found more effective for alginase production. At present, many researchers were investigated and characterized the alginase enzyme for socioeconomic importance.

\section{Conflict of Interest}

There is no conflict in this study.

\section{Acknowledgements}

The facilities provided by Department of Microbiology, Ayya Nadar Janaki Ammal College, Sivakasi to carry out this study are gratefully acknowledged.

\section{REFERENCES}

[1] M. Foschiatti, structure-function relationships of polysaccharides produced by opportunistic pathogens. Annals Accademico. Vol 4, No. 1-127, 2009.

[2] T.J. McCallum, J.M. Milunsky, D.L. Cunningham, D.H. Harris, T.A. Maher, R.D. Oates Fertility in men with cystic fibrosis. An update on current surgical practices and outcomes, Chest. Vol. 118, No. 1059-1062, 2000.

[3] J.B. Lyczak, C.L. Cannon, G.B. Pier. Lung infections associated with cystic fibrosis. Clin. Microbiology Review. Vol. 15 No.194-222, 2002.

[4] N. Nagasawa, H. Mitomo, F. Yoshii, T. Kume, Radiation-induced degradation of sodium alginate. Polymer. Degradation. Stab. Vol. 69, No.279-285, 2000.

[5] Y. Iwamoto, R. Araki, K. Iriyama, T. Oda, H. Fukuda, S. Hayashida, T.Muramatsu. Purification and characterization of bifunctional alginate lyase from Alteromonas sp. strain no. 272 and its action on saturated oligomeric substrates. Bioscience, Biotechnology and Biochemistry. Vol. 65, No.133-142, 2011.

[6] T.Y. Wong, L.A. Preston, and N.L. Schiller. Alginate lyase: Review of major sources and enzyme characteristics, structure-function analysis, biological roles, and applications. 
Annals Review Microbiology. Vol.54, No.289-340, 2000.

[7] M.T. Albrecht, N.L. Schiller. Alginate lyase (AlgL) activity is required for alginate biosynthesis in Pseudomonas aeruginosa. Journal of Bacteriology. Vol. 187, No.3869-3872, 2005.

[8] S.R. Monday, N.L. Schiller. Alginate synthesis in Pseudomonas aeruginosa: the role of AlgL (alginate lyase) and AlgX. Journal of Bacteriology. Vol. 178, No.625-632, 1996.

[9] X.K. Hu, X.L. Jiang, H. Hueymin, S.L. Liu, H.S. Guan. Promotive effects of alginate-derived oligosaccharide on maize seed germination. Journal of Applied Physics. Vol. 16, No.73-76, 2004.

[10] W. Dou, D. Weia, H. Lia, H. Lia, M.M. Rahmana, J. Shi, Z. Xua, Y. Ma Purification and characterisation of a bifunctional alginate lyase from novel Isoptericola halotolerans CGMCC 5336. Carbohydrate. Polymers. Vol. 98, No.1476-1482, 2013.

[11] M. Amani, D. ElAhwany, M. Aliaa, Elborai. Optimization of medium composition for extra cellular alginate lyases of a marine bacterium. African Journal of Microbial Research. 6 (2012) 2403-2409.

[12] C. Mawadza, R. Hatti-Kaul, R. Zvauya, B. Mattiason. Purification and characterization of cellulases produced by Bacillus strain. Journal of Biotechnol.Vol. 83, No. 177-187, 2000.

[13] T. Sawabe, Y. Ezura. T. Kimura, Purification and characterization of alginate lyase from marine Alteromonas sp. Nippon. Suisan. Gakkaishi. Vol.58, No. 521-27, 1992

[14] J.H. Morrissey, Silver stain for proteins in polyacrylamide gels: A modified procedure with enhanced uniform sensitivity. Anals. Biochemistry. Vol.117, No.307-310, 1981.

[15] S. Sankaralingam, T. Shankar, K. Sendeshkannan, R. Ramasubburayan, S. Prakash. Production of Protease from Pseudomonas Sp. by Immobilization Approach on Different Matrices. European. Journal of Applied. Sciences. Vol. 4, No.146-156, 2012.

[16] F. Wang, H. Ni, H. Cai, A. Xiao. Tea stalks a novel agro-residue for the production of tannase under solid state fermentation by Aspergillus niger JMU-TS528. Annals Microbiology. Vol. 63, No.897-904, 2013.

[17] H.C. Lange, D. Beunard, P. Dhulster, D. Guillochon, A.M. Caze, M. Morcellet, N. Saude, G.A. Junter. Production of microbial alginate in a membrane bioreactor. Enzymes and Microbial Technology. Vol.30, No. 656-661, 2002.

[18] J.C. Tang, Q.X. Zhou, H.R. Chu, S. Nagata. Characterization of alginase and elicitor-active oligosaccharides from Gracili bacillus A7 in alleviating salt stress for Brassica campestris L. Journal of Agricultural and Food Chemistry. Vol. 59, No.7896-7901, 2011.
[19] W. Hashimoto, O. Miyake, K. Momma, S. Kawai, A.K. Murata. Molecular identification of oligo alginate lyase of Sphingomonas sp. strain A1 as one of the enzymes required for complete depolymerization of alginate. Journal of Bacteriology.Vol.182, No. 4572-4577, 2004.

[20] R. Matsushima, H. Danno, M. Uchida, K. Ishihara, T. Suzuki, M. Kaneniwa. Analysis of extracellular alginate lyase and its gene from a marine bacterial strain, Pseudoalteromonas atlantica AR06. Applied Microbiology and Biotechnol. Vol.86, No. 567-576, 2010.

[21] U. Beshay, D. Abd-El-Haleem, H. Moaward, S. Zaki. Phenol biodegradation by free and immobilized Acinetobacter. Biotechnol. Lett. Vol. 24, No. 1295-1297, 2002.

[22] S.F. Gauthier, J.C. Vuillemard, N. Lizotte. Immobilization of chymotrypsin and tyrosine on different agarose gels. Journal of Food Biotechnology. Vol. 5, No. 105-117, 1991.

[23] V. Anna, B. Nigar, B. Venko. Cyclodextrin glucanotransferase production by free and agar gel immobilized cells of Bacillus circulans ATCC 21783.Process Biochemistry. Vol.38, No.1585-1591, 2003.

[24] S. Vijayanand, J. Hemapriya, J. Selvin, S. Kiran. Operational Stability and Reusability of Halobacterium sp. JS Cells Immobilized in Various Matrices for Halo alkaliphilic Protease Production. International Journal of Microbiological Research. Vol. 3, No.01-06, 2012.

[25] S.V. Ramakrishna, R.S. Prakasham, Microbial fermentation with immobilized cells. Current Science. Vol. 77, No. 87-100, 1999.

[26] N.F. Zauari, A. Haddar, N. Himidet, F. Frikha, M. Wasri. Application of statistical experimental design for optimization of keratinase production by Bacillus pumilus A1 grown on chicken feather and some biochemical properties. Process Biochemistry. Vol. 45, No. 617-626, 2010.

[27] T. Sivakumar, S. Sivasankaranarayani, T. Shankar, P. Vijayabaskar. Statistical optimization of exopolysaccharide production by Frateuria aurentia. International Journal of Biological and Pharmaceutical Research. Vol. 3, No. 457-462, 2012.

[28] E. Tiwary, R. Gupta. Extracellular expression of keratinase from Bacillus licheniformisER-15 in Escherichia coli. Journal of Agricultural and Food Chem. Vol.58, No. 8380-8385, 2010.

[29] L.V. Xian, M.H. Sim, Y.D. Li, J. Min, W.H. Feng, W.J. Gban, Y.G. Li. Production, characterization and application of a keratinase from Chryseo bacterium 299 sp. Nov. Process Biochemistry. Vol. 45, No.1236-1244, 2010.

[30] T. Matsui, Y. Yamada, H. Mitsuya, Y. Shigeri, Y. Yoshida, Y. Saito, H. Matsui, K. Watanable. Sustainable and practical degradation of intact chicken feathers by cultivating isolated thermophilic Meiothermus ruber $\mathrm{H}$ 328. Applied Microbiology and Biotechnology. Vol. 82, No. 941-950, 2009. 